gates, each $20 \mathrm{ft}$. wide, and there is a small navigation lock. The constructional operations were seriously hampered in November 1936 by extensive rains, which produced the highest flood on record on the Tigris for that season of the year, and rose with such unprecedented rapidity that the works were entirely inundated and brought to a standstill. A further difficulty was the extraordinary range of temperature, which varied from freezing point in winter to $125^{\circ} \mathrm{F}$. in the shade in summer. The engineers for the undertaking were Messrs. Coode, Wilson, Mitchell and Vaughan-Lee of Westminster, and the contract was entrusted to Messrs. Balfour, Beatty and Co., Ltd., of London.

\section{School of Oriental Studies}

ThF School of Oriental Studies in the University of London, it is stated in the report of the Governing Body for the academic year 1937-38, will vacate the premises at Vandon House, Westminster, now in temporary occupation, for the new building on the Bloomsbury site of the University, in March 1941. Owing to the inconvenience of present arrangements, removal at the earliest possible date has become imperative. At the moment, not only has the library to be housed in another part of Westminster, away from the academic and administrative work of the School, but also a large part of the collection of Chinese and Far-Eastern books, some 16,000 in number, brought together by the late Sir Reginald F. Johnston, professor of Chinese in the University of London, and presented to the library by his executrix, cannot be utilized and must be kept in store. The work of the School, which covers a wide range, now includes in addition to the study of languages, lectures on the religions of the Orient, Indian art, archæology, and philosophy, Burmese law, history, and economics, Buddhist law, and Indian social welfare. In the school of languages during the academic year instruction was given in Arabic, Persian, Sanskrit, Malay, Hindustani, Chinese, Japanese, and Burmese, the number of students in each being in the order named; while in the African Department there were students in such little known tongues as Efik, Ibo, Lunyoro, Shona, Tswana, Twi, Yao, Yoruba, and Zande. The extent to which these facilities are appreciated is shown by the fact that there were in 1937-38, 85 full-time students, 94 part-time, 197 occasional, and 73 inter-collegiate students, making 449 in all, an increase of 21 on the numbers of the preceding year. Since the death of Sir Montague Butler, chairman of the governing body, in March last, Lord Harlech, formerly Secretary of State for the Colonies, has accepted that office.

\section{Geological Museum : Recent Acquisition}

RECENT additions to the collections of the Geological Museum include a number of specimens of beautifully banded pink rhodochrosite, from Minas Capillitas, Catamarca, Argentina. This mineral, which is the carbonate of zine, is of a rich pink colour, the specimens being of stalactitic formation. Although previously employed as a semi-precious stone, its use has hitherto been relatively rare: but rhodochrosite from the same source as the Museum specimens was recently utilized in London under the name of 'Inca Rose', in various Christmas gifts, to form an inlay at the edges of white marble-onyx eigarette boxes, and in similar ornamental work in which malachite or lapis lazuli is frequently used. The mineral was collected by Dr. Franz Mansfeld from an old mine, until recently deserted, situated at an altitude of about 10,000 ft., in the Andes. The Museum has also received as a gift from Mr. T. C. F. Hall a small collection of specimens of alluvial gold from Abyssinia and Korea. The Abyssinian specimens include a sample of gold dust, associated with particles of iron ore, in a feather quill, as brought in by the natives. Other acquisitions include two very fine stalagmitic and stalactitic specimens of melanterite (ferrous sulphate) from Millclose Mine, Warrencar, Derbyshire, presented by Prof. W. G. Fearnsides; and a large crystal of corundum or impure ruby some five inches in length and three inches in diameter. A number of specimens of seepages of mineral oil found associated with British coal-seams have also been placed on exhibition.

\section{Articulation of Secondary with University Education}

THE United States Office of Education has issued a report, entitled "Some Factors in the Adjustment of College Students", of elaborate investigations of university entrance conditions in relation to the varying needs and capacities of individual students. Seven factors have been studied: articulation of high-school and university subject areas, extracurricular activities, lapse of time between leaving high school and admission to university, age on admission, high-school marks, aptitude and achievement test results, effect on university students of simultaneously engaging in gainful occupations. It is suggested that university courses be made to fit entering students either by dovetailing them with the high-school courses or "by setting up a few broad, comprehensive courses which challenge the interest and ability of the student" as in the University of Chicago (the humanities, the social sciences, the physical sciences, and the biological sciences). The report concludes with a formulation of the following desiderata : a more comprehensive system of recordkeeping in the high-school for use in guidance of students; utilization by universities in admitting or guiding the student of as many items of knowledge concerning him or her as possible and, to this end, the provision by them of facilities for testing and interviewing them; integration of the work of the high school and the university through facilities for students of different levels of general scholastic aptitude; and shepherding of students into particular courses in accordance with their past achievements.

\section{Library Service in the United States}

A REPORT on library service, prepared by C. B. Joeckel for the Advisory Committee on Education, has been issued by the U.S. Government Printing Office. The survey indicates that the total library 